\title{
COMPARISON OF SMOKERS EMPLOYMENT STATUS IN RETENTION BEHAVIOR AMONG COMMUNITY IN TERENGGANU
}

\author{
M. S. N. ABU HASSAN ${ }^{1}$, M. S. SA'ID ${ }^{2}$, N. NAZARUDIN ${ }^{3}$, M.K.A. KAMARUDDIN ${ }^{4}$, \\ M.I. JAYA ${ }^{5} \&$ MOHD ARMI ABU SAMAH ${ }^{6}$ \\ ${ }^{1,2,3,4}$ Faculty of Applied Social Science, Universiti Sultan Zainal Abidin, Terengganu, Malaysia \\ ${ }^{5}$ Faculty of Computing, University Malaysia Pahang, Kuantan, Malaysia \\ ${ }^{6}$ International Islamic University Malaysia, 25200, Kuantan Pahang
}

\begin{abstract}
Smoking is one of the behaviors that violates the norms of life because it causes harm to oneself and to the environment. Smoking problems are no longer an unfamiliar behavior for working and non-working people where they have easy access to the material. The purpose of this study was to identify comparisons between working smokers and non-smokers in maintaining smoking behavior. This study uses quantitative techniques for the purpose of obtaining accurate answers from respondents. The respondents of this study were 437 male respondents living in Terengganu state. The analysis used in this study was discriminant analysis. This discriminant analysis aims to control for variables that separate between three or more clusters that are clearly joined. Discriminant Analysis (DA) uses misclassified modes, backward stepwise, and forward stepwise. Standard mode reported $95.88 \%$ gain with 21 variables while backward stepwise and forward stepwise recorded $95.19 \%$ with 10 variables for backward stepwise and 7 variables for stepwise forward. Some of the significant questions with the number 0.0001 were S1, S2, S4, S6, S9, S13, and S18. The government should play a role in drafting strategies for law enforcement to combat the growing prevalence of smoking.

KEYWORDS: Smoking, Working Status, Youth
\end{abstract}

Received: Jun 08, 2020; Accepted: Jun 28, 2020; Published: Sep 24, 2020; Paper Id.: IJMPERDJUN20201398

\section{INTRODUCTION}

The study was focused on the comparison of working smokers with non-smokers in maintaining the smoking behavior of people in Terengganu. Smoking is one of the social problems most often encountered by the local community, especially among the unemployed. Statistics released by the Ministry of Health Malaysia (2005) indicate that about 45 to 59 teenagers under the age of 18 start smoking cigarettes in the country (8). Today's rise in smoking behavior is alarming to all parties, especially parents as they are still underage and their responsibility to serve both parents is different from that of a smoker who works where they have the financial means to access the material. However, there is a comparison of smokers working and unemployed smokers.

Comparison factors of smokers working with unemployed are influenced by the surrounding community. This is because, young people are very easily influenced by peers who often ask them to try something new. Whereas the working class is caused by their own co-workers or employers because of their behavior in honor of their superiors. This behavior is synonymous with youths who feel like trying something new without risking the people 
around them. Therefore, all parties need to take an initiative in preventing this smoking behavior from being practiced where this behavior is a violation of the norms of life and disrupts the social system's society today. One initiative that has been undertaken in an effort to curb this behavior is that the government has launched a smoking awareness campaign in all mediums so that all information reaches all ages (1).Smoking behavior will have a negative effect on the perpetrator as well as those around him. Women and children are among the most affected by the disease as a result of smoking behavior in public. Health reports indicate that 80 percent of the risk of a dangerous illness is caused by cigarette smoke affecting the women and children. According to Health Clinic Medical Officers, although the group did not do so, the exposed cigarette smoke caused them to suffer from dangerous diseases such as cough, heart disease and headache. Smokers should be aware of the impact on people around them when they engage in such behavior in public or in public. This is because the content of the cigarette smoke is similar to that of a smoker containing nicotine and toxic chemicals (7).

Cigarette abuse behaviors have had a detrimental effect on the retention of smokers working and not working. The researcher has set several objectives to guide this study until the end of the study. One of the objectives is to see how much smoking behavior among smokers who have not worked affect the smoking cessation factor.

\section{MATERIAL AND METHOD}

\section{A. Participants}

This study collected 437 respondents whose questionnaires were distributed randomly. This is because the researchers want to get the whole data or information and can be used as a representative to continue this study (5). This study uses quantitative techniques for the purpose of obtaining accurate answers from respondents. This study was conducted in one of the states on the east coast of peninsular Malaysia. This study focuses on young people between the ages of 15 and 40 . The study found that 437 male respondents and all respondents were Terengganu residents.

\section{B. Instrument}

The study used a sampling method aimed at obtaining 437 respondents. The sustainability of this study required 210 people to reach the level of reliability of this study. The G-Power application used is to determine the sample size. This study used Discriminant analysis aimed at controlling variables that split between three or more clusters (2). The questionnaire used in this study was that the respondents were provided with a two-part questionnaire form part A and part B. Part A was a demographic question and part B questionnaire had 21 questions.

\section{Statistical Analysis}

Pre-processing data: The youth matrix set containing 9177 (21 variables x 437 respondents) was calculated in this study. The research matrix has a small loss of data ( 3\%) of all recorded data, while the neighbor method can also be used (9)(2). This method examines the distance between each point and the point closest to it (11). The neighboring method used in this study is the simplest method, where the endpoint of the gap is used as an estimate of all missing values (2).

Discriminant Analysis: Discriminant analysis is a technique that is used by the researcher to analyze the research data when the criterion or the dependent variable is categorical and the predictor or the independent variable is interval in nature(4). The term categorical variable means that the dependent variable is divided into a number of categories. 


\section{RESULT AND DISCUSSIONS}

\begin{tabular}{|l|c|c|c|}
\hline \multirow{2}{*}{ Sample groups } & \multirow{2}{*}{ \% Correct } & \multicolumn{2}{c|}{ Group Assigned by DA } \\
\cline { 3 - 4 } DA (21 independent variable). & & & Working \\
\hline \multicolumn{1}{|c|}{} & $65.91 \%$ & 29 & 15 \\
\hline Working & $99.24 \%$ & 3 & 390 \\
\hline Unemployed & $95.88 \%$ & 32 & 405 \\
\hline Total & & & \\
\hline $\begin{array}{l}\text { Backward stepwise (10 independent } \\
\text { variable) }\end{array}$ & & 31 & 13 \\
\hline Working & $70.45 \%$ & 8 & 385 \\
\hline Unemployed Total & $97.96 \%$ & 39 & 398 \\
\hline Total & $95.19 \%$ & & 16 \\
\hline Forward stepwise (7 independent variable) & & 28 & 388 \\
\hline Working & $63.64 \%$ & 5 & 404 \\
\hline Unemployed & $98.73 \%$ & 33 & \\
\hline \multicolumn{2}{|c|}{} \\
\hline
\end{tabular}
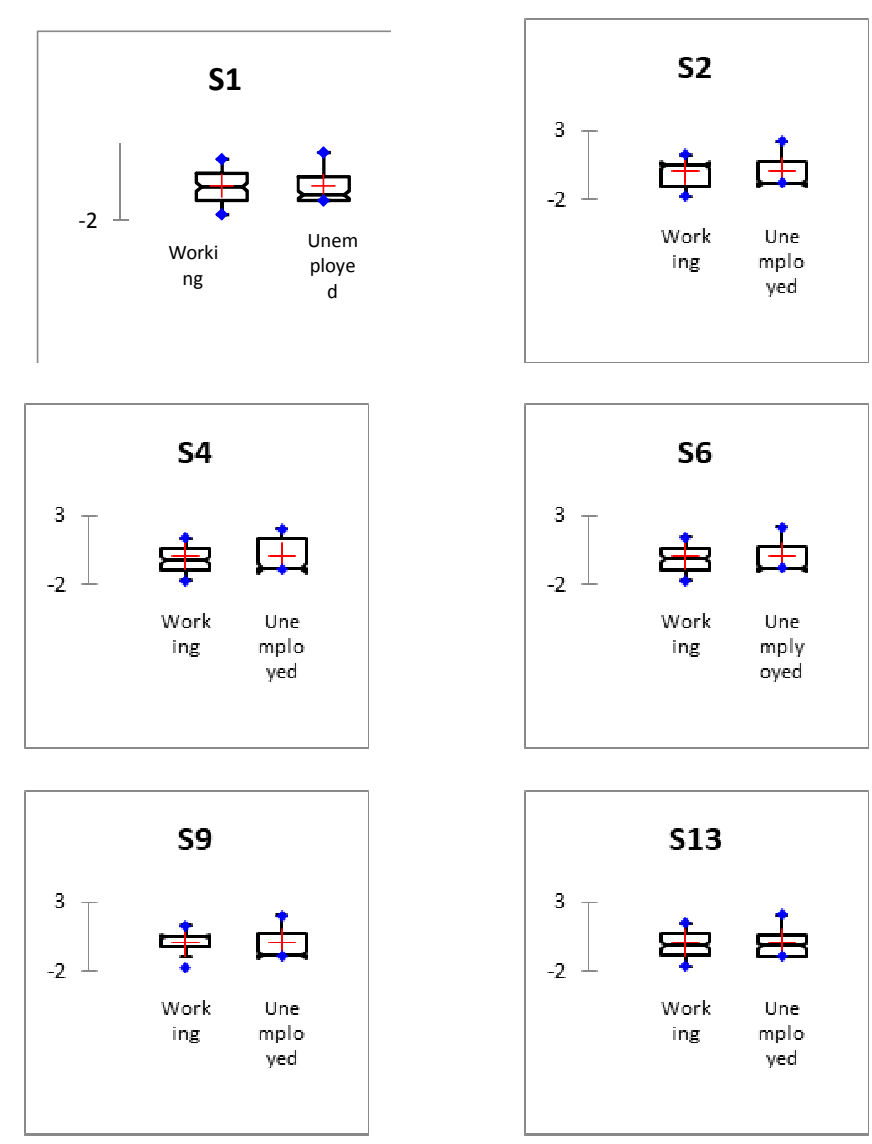

S13
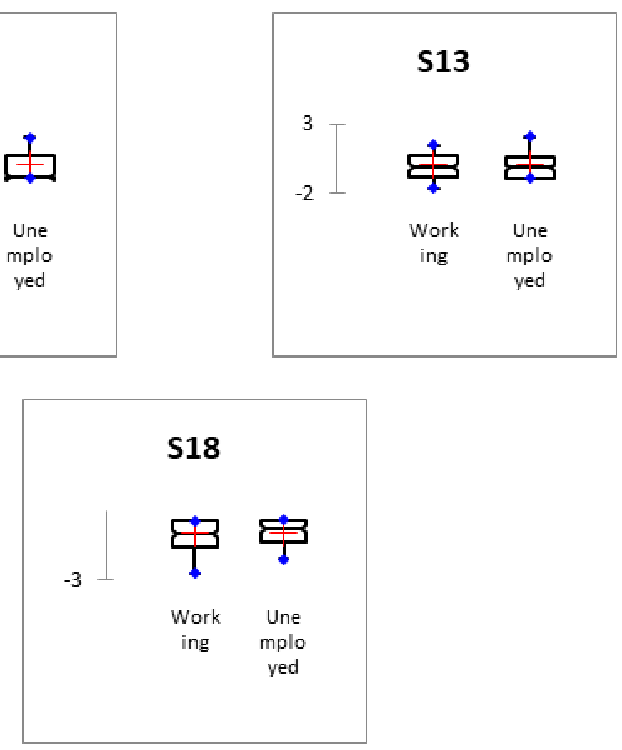

Figure 1: Box plot dari Stepwise mode. 
Discriminant Analysis (DA) uses misclassified modes, backward stepwise, and forward stepwise. Standard mode reported $95.88 \%$ gain with 21 variables while backward stepwise and forward stepwise recorded $95.19 \%$ with 10 variables for backward stepwise and 7 variables for stepwise forward. Some of the significant questions with the number 0.0001 were $\mathrm{S} 1$, S2, S4, S6, S9, S13, and S18. Question Q1 is that cigarette taste is very good, respondents strongly disagree with the idea of cigarette smoking. S2 respondents argued that cigarettes do not control their appetite. S4 is that respondents do not feel sensation while smoking. The S6 is a cigarette that can't quench my appetite. S9 is the respondent strongly disagree with the enjoyment of cigarettes. S13 was the respondent saying that smoking does not control weight. Finally, S18 respondents were aware of the dangers of cigarettes to consumers and passive smokers.

Normal analysis of the standard (standard mode), Among the significant questions with 0.0001 are S1, S2, S3, S4, S5, S6, S7, S8, S9, S10, S12, S13, S14, S16, S17, S19, S20 and S21. This shows that smokers who work and who do not work find smoking very tasty and can control their appetite. Cigarettes can also help them deal with problems and they can enjoy the sensation while smoking. Smoking can help you overcome depression, refrain from eating too much and deal with anger. Smoking can give them the pleasure and enjoyment of the cigarette because they can feel the pleasure of smoking on the tongue and lips. Smoking also helps reduce and control tension which helps control weight. Smoking can also help to overcome frustration. Smoking can prevent obesity and lose weight. Smoking can be calming when nervous and angry. Finally, they say that cigarettes are a part of their lives.

Then discriminant analysis (stepwise withdrawal), Among the significant questions with the number 0.0001 were S1, S2, S4, S6, S7, S8, S9, S12, S13, and S18. This shows that, smokers who are working and who have not been working think that smoking is very good and can control their appetite. They can enjoy sensation while smoking and can avoid over eating. Smoking can help them deal with anger and calm them down. They can enjoy the taste of cigarettes and help them reduce and control tension. Finally smoking helps them control their weight. But they also think that smoking can endanger their health.

Finally a stepwise analysis, among the significant questions with the sum of 0.0001 are S1, S2, S4, S6, S9, S13, and S18. This shows that smokers who work and who do not work find smoking very tasty and can control their appetite. They can enjoy sensation while smoking and can avoid over eating. They can enjoy the taste of cigarettes and control their weight. But they also think that smoking can endanger their health

Social workers are responsible for stemming this growing trend in society in our country. This is because social workers have their own roles that can be used to shape the social system (1). To enhance this individual's social function is to restructure the existing social system as each individual has his or her own right in life. In addition, the role of the surrounding community or the youth also helps to change these smoking behaviors to achieve universal harmony and also enhance their social functioning.. Furthermore, the role of parents is one of the measures to curb smoking behavior where parents should monitor their children's movement both at home and outside the home. Parents should ask their children where they invest their money in their daily lives to curb their children buying cigarettes (13).

\section{CONCLUSIONS}

The findings of this study show that the youth behavior in Terengganu is likely to be related to smoking or non-working behavior. It is concluded that young men in Terengganu are less aware of the negative consequences of this behavior. The power amplifier plays a role in preventing youth from accessing this prohibited material, especially to minors. Therefore, the 
public needs to correct the perception of the people in rejecting this culture from being a process of normalization in the public environment.

\section{ACKNOWLEDGMENT}

The researcher thanked the Research and Development Management Unit, Sultan Zainal Abidin University (UniSZA), Kuala Terengganu for providing space and utilities for this study.

\section{REFERENCES}

1. Abdul Razak Abd Manaf, N. F. (2012). Asas-Asas Amalan KERJA SOSIAL. Universiti Utara Malaysia.

2. A., B. H. M. Maliki, M. R. Abdullah, H. Juahir, F. Abdullah, N. A. S. Abdullah, R. M. Musa, S. M. Mat-Rasid, A. Adnan, N. A. Kosni, W. S. A. W. Muhamad, and N. A. M. Nasir, “A multilateral modelling of Youth Soccer Performance Index (YSPI),” IOP Conference Series: Materials Science and Engineering, vol. 342, p. 012057, 2018.

3. Ali, D. A. (25 Jun, 2014). Merokok. Retrieved 14 Julai, 2019, from My Health for life: http://www.myhealth.gov.my/merokok/

4. B. H. M. Maliki, M. R. Abdullah, H. Juahir, W. S. A. W. Muhamad, N. A. M. Nasir, R. M. Musa, S. M. Mat-Rasid, A. Adnan, N. A. Kosni, F. Abdullah, and N. A. S. Abdullah, "The role of anthropometric, growth and maturity index (AGaMI) influencing youth soccer relative performance,” IOP Conference Series: Materials Science and Engineering, vol. 342, p. 012056, 2018.

5. Chua, Y. P. (2011). Kaedah dan statistik penyelidikan: kaedah penyelidikan. Mcgraw-Hill Education.

6. George Ritzer, D. G. (2009). Teori Sosiologi Dari Teori Sosiologi Klasik Sampai Perkembangan Mutakhir Teori Sosial Postmodern. Jogyakarta: Kreasi Wacana.

7. Jasman, N. b. (2016, Februari 7). Merokok Satu Amalan Yang Tidak Boleh Diterima Masyarakat. Retrieved July 7, 2019 , from My Health for life: http://taknak.myhealth.gov.my/merokok-satu-amalan-yang-tidak-boleh-diterima-oleh-masyarakat/

8. KALAM, H. B. B. A. (2016). Pengaruh Persekitaran Sosial Terhadap Tingkah Laku Disiplin Murid Sekolah Rendah Di Klang, Selangor, Malaysia.

9. M. H. Abdullah, H. Juahir, F. Lananan, M. K. A. Kamarudin, A. Ghazali, A. Azemin, N. J. A. Wahab, S. M. Mat-Rasid, and M. H. M. Saad, "Pattern Recognition of Melaleuca cajuputi Powell Essential Oils Fingerprint in Terengganu, Malaysia Using Chemometric Approach,” International Journal of Engineering \& Technology, vol. 7, no. 3.14, p. 132, 2018.

10. Mohd Fadli, R. (2011). Penggunaan kesan khas" particle illusion" dalam iklan kempen anti merokok (Doctoral dissertation, Fakulti Teknologi Kreatif dan Warisan).

11. M. S. N. Abu Hassan, M. K. A. Kamarudin, M. H. M. Saad, N. A. Wahab, U. H. N. A. Sabri, W. N. W. Hashin, N. S. Wahab, R. N. S. R. M. Yusoh, and N. A. F. Yusoff, “Death Rate Analysis Due to Suicide,” International Journal of Engineering \& Technology, vol. 7, no. 4.34, pp. 56-60, 2018.

12. Neuman, M. D. (2005). Tobacco Industry Influence on The Definition of Tobacco. Reseach Paper, 328-337.

13. Ooi, E. T., \& Rahabah, A. (2003). Kajian Kesan Merokok Terhadap Kadar Pengambilan Oksigen Maksimum (vo2max) Melalui Pengambilan Kadar Nadi Latihan Di Kalangan Pelajar-pelajar Lelaki Tahun 4 Sains Sukan, Utm, Skudai, Johor (Doctoral dissertation, Universiti Teknologi Malaysia).

14. Pratama, R. Y. (2013). Museum Kretek Dan Pelestarian Peninggalan Sejarah Industri Rokok Kretek Kudus Tahun 1986-2010 (Doctoral dissertation, Universitas Negeri Semarang). 
15. QURNAENI, N. (2017). Implementasi Peraturan Daerah Kota Makassar Nomor 4 Tahun 2013 Tentang Kawasan Tanpa Rokok Di Kota Makassar (Doctoral dissertation).

16. Shahar. (2018). Wanita, kanak-kanak menderita kesan asap rokok. Berita Harian

17. Sholihin, M. (2009). Perilaku Pemilih Buruh Rokok Dalam Pilkada Langsung Di Kabupaten Kudus (Doctoral dissertation, Program Pascasarjana Universitas Diponegoro).

18. Skidmore, T. F. (2000). Introduction to social work. MA: Pearson Allyn \& Bacon

19. Tunggak, B., Ngadi, S., \& Naim, H. A. (2015). Delinkuen Pelajar Dan Cadangan Penyelesaiannya Menerusi Model Pembangunan Sahsiah Remaja/Pelajar Muslim Bersepadu (Students Delinquency and Proposed Solutions Through Teen Model of Conduct/Integrated Muslim Students). Jurnal Hadhari: An International Journal, 7(2), 11-30.

20. Zastrow. (2010). The Practice of Social Work: A Comprehensive Worktext. USA: Brooks/Cole. 